\title{
Innovative oligomeric poly(vinyl chloride) plasticizers for specialized applications
}

\author{
Marek Lewandowski ${ }^{1)}{ }^{*}$,, Kazimierz Piszczek ${ }^{2)}$, Marta Pieńkowska ${ }^{1)}$, Krzysztof Lewandowski ${ }^{2)}$ \\ DOI: dx.doi.org/10.14314/polimery.2020.7.7
}

\begin{abstract}
The purpose of the work was to determine the properties of poly(vinyl chloride) (PVC) plasticized with a new linear and oligomeric terephthalic acid esters and aliphatic acids in terms of their application as an innovative non-phthalate plasticizers. On the basis of analysis of PVC grain swelling shows that these compounds have plasticizing properties. Plastographometric tests were performed, the glass transition temperature and thermal stability time were analyzed. The mass flow rate (MFR) and mechanical properties of plasticized PVC was determined. Based on the analysis of the results obtained, it can be concluded that both assessed oligoesters can be successfully used for the production of plasticized PVC with utility indicators similar to those of plasticized PVC produced so far.
\end{abstract}

Keywords: PVC, plasticizers, oligomeric terephthalic acid esters, oligomeric adipic acid esters.

\section{Innowacyjne plastyfikatory oligomeryczne poli(chlorku winylu) do aplikacji specjalistycznych}

Streszczenie: Zbadano właściwości poli(chlorku winylu) (PVC) plastyfikowanego przy użyciu nowatorskich bezftalanowych plastyfikatorów PVC - liniowych oligomerycznych estrów kwasu tereftalowego i estrów kwasów alifatycznych. Analiza kinetyki pęcznienia ziaren PVC w funkcji temperatury potwierdza, że związki te wykazują właściwości plastyfikujące. Wykonano badania plastografometryczne, oznaczono temperaturę zeszklenia i czas stabilności termicznej. Wyznaczono masowy wskaźnik płynięcia (MFR) oraz określono właściwości mechaniczne wytworzonych plastyfikatów. Stwierdzono, że oba oceniane oligoestry można z powodzeniem zastosować do wytwarzania plastyfikatów o wskaźnikach użytkowych podobnych do wskaźników dotychczas wytwarzanych plastyfikatów.

Słowa kluczowe: PVC, plastyfikatory, oligomeryczne estry kwasu tereftalowego, oligomeryczne estry kwasu adypinowego.

Solubility of polymers was an important issue already in the early period of polymer research. are It was noticed then that there a lot of substances that can dissolve poly(vinyl chloride) (PVC) [1-3]. On the basis of the results of the research, a group of plasticizer compounds was established, which can form durable, flexible materials of PVC useful in practice for various applications [4-12]. Plasticization has become one of the basic methods of modification of physical properties of PVC. It involves the preparation of mixtures of primary unprocessed PVC powder with plasticizers, which, having been processed, become homogeneous materials.

In PVC macromolecules, electronegative chlorine atoms covalently attached to every second carbon atom

\footnotetext{
1) Purinova Sp. z o.o., Bydgoszcz, Wojska Polskiego 65, 85-825 Bydgoszcz, Poland.

2) UTP University of Science and Technology in Bydgoszcz, Faculty of Chemical Technology and Engineering, Seminaryjna 3, 85-326 Bydgoszcz, Poland.

*) Author for correspondence: m.lewandowski@purinova.com
}

are stable dipoles distributed evenly along the polymer chain $[1,2,13]$. Strong interactions between dipoles of adjacent macromolecules influence the observed PVC rigidity and relatively high glass transition temperature $\left(T_{g}\right)$ [14-16]. Intermolecular interactions can be effectively reduced by plasticizing. Plasticizers reduce the glass transition temperature and the melting temperature, as a result of which their processing and utility properties also change [4-12, 17, 18]. Therefore, plasticizers must be constructed so that their molecules contain groups capable of increasing the mobility of adjacent chains by weakening the interaction between dipoles and increasing the distance between PVC macromolecules. Chemical compounds that are to act as a PVC plasticizer must act like good solvent. At the same time, should have the right viscosity that allows easy dosing. In addition, they should be characterized by high boiling point (at least $280^{\circ} \mathrm{C}$ ), good efficiency and heat stability. Soft PVC obtained with the participation of plasticizers should show high resistance to extraction and no tendency to migrate. In addition, they should meet the required functional features, 
including no adverse impact on human health [6, 19-21]. Phthalates are a very effective group of plasticizers. An exposed aromatic ring is present in their molecule. It forms strong induced dipole and two ester groups as well as the associated aliphatic chains that make it difficult for adjacent PVC chains to approach each other. Such plasticizers are mixed with PVC in any proportions and can form real solutions with it. This group also includes monomeric plasticizers with molecular weight up to 500 . In recent years, there have been reports suggesting the harmful effects of phthalate plasticizers on human health $[22,23]$. For this reason, they have been withdrawn from production practice [24, 25]. Instead of phthalate esters, terephthalate esters are currently proposed, but their synthesis can encounter major preparatory difficulties.

Plasticizers with molecular weights higher than 500, so-called polymeric plasticizers, have a lower plasticizing efficiency compared to monomeric plasticizers, and therefore the processing of plasticizers with their participation is more difficult. However, materials containing them show high resistance to extraction and migration. In practice, mixtures of various plasticizing substances selected in such a way that the properties of the obtained material meet the requirements of future users are often used. Despite the considerable amount of knowledge about PVC plasticization, research is still carried out to obtain and introduce into production new plasticizers that are better and better adapted to modern requirements [26-35].

An attempt was made to develop new plasticizers for PVC, which can be an alternative to compounds based on phthalates as part of the project "Obtaining innovative polymeric surfactants and plasticizers, which can simultaneously have the properties of surfactants for the processing of plastics" (POIR.01.01.01-00-0172/15-02) at Purinova Sp. z o.o. in Bydgoszcz, in cooperation with the Department of Polymer Technology and Protective Coatings of University of Technology and Life Sciences in Bydgoszcz. The purpose of this work is to determine the properties of linear oligomeric terephthalic acid esters and oligomeric aliphatic acid esters obtained as part of the project in terms of their use as innovative phthalatefree PVC plasticizers.

\section{EXPERIMENTAL PART}

\section{Materials}

Oligomeric terephthalic acid ester with polyethylene glycols (PureFlex A) and the oligomeric ester of adipic and succinic acids with diethylene glycol and 2-ethylhexyl alcohol (PureFlex B) synthesized at Purinova Sp. $z$ o.o. in Bydgoszcz were used as plasticizers. The basic characteristics of oligoesters are summarized in Table 1.

\section{Preparation of PVC mixture}

For testing, a PVC mixture was used, consisting of: PVC Neralit 601 (Spolana s.r.o.) (100 phr), stabilizer (4 phr) and PureFlex A or PureFlex B in an amount of $20 \mathrm{phr}$, $30 \mathrm{phr}$ or $40 \mathrm{phr}$, respectively. The mixtures prepared in a Z-mixer (Brabender PL) at $105^{\circ} \mathrm{C}$ for 15 minutes were used for plastographometric tests and extrusion with a laboratory extruder $(D=15 \mathrm{~mm}, L / D=14$, Brabender FDO $234 \mathrm{H}$ ), equipped with a head with a $3 \mathrm{~mm}$ diameter and $30 \mathrm{~mm}$ long nozzle. The temperature of the first zone of the plasticizing system was $100^{\circ} \mathrm{C}$, the second zone $170^{\circ} \mathrm{C}$, the connector and the head $170^{\circ} \mathrm{C}$, the rotation speed of the screw $50 \mathrm{rpm}$. Having been cooled, the obtained residues were granulated and then formed as plates using a hydraulic press (ANMIR). The pressing temperature was $170^{\circ} \mathrm{C}$, the time of preheating the material -3 minutes, pressing at $5 \mathrm{MPa}-2$ minutes. The obtained $120 \times 120 \times 2 \mathrm{~mm}$ or $100 \times 100 \times 1 \mathrm{~mm}$ plates were used for testing mechanical properties.

\section{Methods of testing}

The initial assessment of the ability to plasticize PVC was made on the basis of analysis of PVC grain swelling in a plasticizer [36-38]. An Nikon Eclipse E400POL optical microscope with a heating table was used for observation. A drop of plasticizer was applied to the PVC Neralit 601 grains placed on the glass plate. The preparation was then heated at a heating rate of $2^{\circ} \mathrm{C} / \mathrm{min}$ and a series of pictures was taken. Based on the measurements of the

T a b l e 1. Properties of PureFlex A and PureFlex B oligoesters

\begin{tabular}{l|c|c|c}
\hline \multirow{1}{*}{ Properties } & Determination method & PureFlex A & PureFlex B \\
\cline { 3 - 4 } & & \multicolumn{2}{|c}{ Value } \\
\hline $\begin{array}{l}\text { Acid number } \\
L_{\mathrm{KW}} \text { mg KOH/g }\end{array}$ & Titration/phenolphthalein & 0.56 & 0.40 \\
$\begin{array}{l}\text { Dynamic viscosity } \\
\text { m.Pas }\end{array}$ & PN-EN ISO 2555:2018-07 & 39 & 419 \\
$\begin{array}{l}\text { Partial mass } \\
\text { Da }\end{array}$ & Gel chromatography & approx. 1000 & approx. 1300 \\
$\begin{array}{l}\text { Volatile matter } \\
\%\end{array}$ & $100^{\circ}$ C, weight method & 0.2 & 0.2 \\
$\begin{array}{l}\text { Absorption of plasticizers } \\
\text { g/100 g PVC }\end{array}$ & PN-EN ISO $4608: 1999$ & 36 & 32 \\
\hline
\end{tabular}


recorded images, changes in the diameter of PVC grain (expressed as a percentage) were determined depending on the temperature. Measurements were made using the NIS-Elements 4.0 software. The measurement was made at least three times.

The process of dry blend formation was determined by a plastographometric method. A plastograph meter (Brabender FDO 234H) equipped with a $50 \mathrm{~cm}^{3}$ chamber was used, into which $65 \mathrm{~g}$ of PVC Neralit 601 mixed at room temperature (100 phr) with the tested oligoester (30 phr) was dispensed. Mixing was carried out at 90, 100 and $120^{\circ} \mathrm{C}$. The rotor speed of the faster rotor was $15 \mathrm{rpm}$, friction $1: 1.5$. Torque changes as a function of time were recorded.

The processing properties of the prepared mixtures were determined in the course of their processing in a plastograph chamber (Brabender FDO 234H); rotation changes and temperature of kneaded material over time were recorded. The tests were carried out at $170^{\circ} \mathrm{C}$, at $30 \mathrm{rpm}$ of the main rotor speed. The measurements were made with a constant weight of $65 \mathrm{~g}$. Characteristic values were read from the plastograms: $M_{x}$ - maximum rotation at the gel point $(x), T_{x}$ - temperature at the gel point, $t_{x}-$ time to reach the gel point, $M_{e}$ - rotation at the end point, $\mathrm{T}_{\mathrm{e}}$-temperature at the end point. The plastographometric tests of each mixture were repeated three times.

Mass melt flow rate (MFR) was determined using a capillary load plastometer (Dynisco LMI 4004), in accordance with the guidelines of PN-EN ISO 1133. The measuring temperature was $175^{\circ} \mathrm{C}$; the nominal load was $21.6 \mathrm{~kg}$. The measurement was made three times.

Mechanical properties were determined at static tensile (Zwick/Roell Z010, with a force measuring head up to $5 \mathrm{kN}$ ), with a test speed of $50 \mathrm{~mm} / \mathrm{min}$, using test specimens in accordance with PN-EN ISO 527-2, type 5A. Strength $\left(\sigma_{m}\right)$ and strain at strength $\left(\varepsilon_{m}\right)$ were determined. In addition, the tensile modulus $\left(E_{t}\right)$ at a speed of $1 \mathrm{~mm} / \mathrm{min}$ was determined. The length of the measuring section equal to the length of the sample limited by parallel edges, i.e. $25 \mathrm{~mm}$, was adopted for the tests. The measurement was repeated five times.

The thermal stability time was determined with the Congo red method. A plastic sample (approx. $0.5 \mathrm{~g}$ ) was placed in a glass tube with an internal diameter of $4.7 \mathrm{~mm}$ and a wall thickness of $0.65 \mathrm{~mm}$. In the upper part of the tube, Congo indicator paper was inserted at a depth of $3 \mathrm{~mm}$. The tube was placed in a stand so that its end was immersed in an oil bath heated to $200^{\circ} \mathrm{C}$. The result of the test involves the time determined as the first visible change in the color of the indicator paper, which indicates the beginning of the destruction of the material and the evolution of hydrogen chloride as a decomposition product of PVC. The presented results are the average of three measurements.

The glass transition temperature $T_{g}$ was determined based on the course of changes in the value of the storage modulus $\left(E^{\prime}\right)$ depending on the temperature. The tests were carried out using the DMA Artemis device from the Netzsch Group (Germany, Selb). The determination was carried out in a three-point bending system (support spacing $20 \mathrm{~mm}$, sample width $10 \mathrm{~mm}$, sample thickness $1 \mathrm{~mm}$ ), with a deformation of $10 \mu \mathrm{m}$ in the temperature range $-140^{\circ} \mathrm{C}-120^{\circ} \mathrm{C}$ with a growth rate of $2^{\circ} \mathrm{C} / \mathrm{min}$. The deformation was set at a frequency of $1 \mathrm{~Hz}$. The relatively low amplitude and low deformation frequency allow measurement in the range of linear viscoelasticity and low value of the loss modulus [41,42]. The range of glass transition was characterized as the onset of a sharp decrease in the value of $E^{\prime}$ ( $T_{g}$ onset).

\section{RESULTS AND DISCUSSION}

Figure 1 presents examples of characteristic stages of PVC grain swelling, and Fig. 2 presents their swelling curves.

The curves of PVC grain swelling (Fig. 2) have a typical course characteristic of undisturbed PVC grain swelling in conventional plasticizers [36-38]. At the first stage of swelling, at a temperature of approx. $79^{\circ} \mathrm{C}$ in PureFlex A and approx. $70^{\circ} \mathrm{C}$ in PureFlex B, capillary penetration of the oligoester inside the PVC grains occurs, which is accompanied by a sharp increase in their size. In the final stage, the PVC grains are completely dissolved so that you can no longer see the border of their contours (Fig. 1). In the case of the PureFlex B sample, the swelling ends with complete dissolution of PVC grains at $119^{\circ} \mathrm{C}$, and in the case of the PureFlex A sample up to a temperature of approximately $125^{\circ} \mathrm{C}$, the grain contours are recognizable.

Figure 3 shows, for example, plastograms of the dry blend process of PVC/PureFlex A.

Having loaded the chamber with the PVC/PureFlex A mixture, the mixture is heated and the oligoester gradually penetrates the grains. Increased rotation is observed as a result of increased friction resulting from an increase in the volume of PVC grains and a decrease in the content of not bonded with PVC plasticizer. At $90^{\circ} \mathrm{C}$,

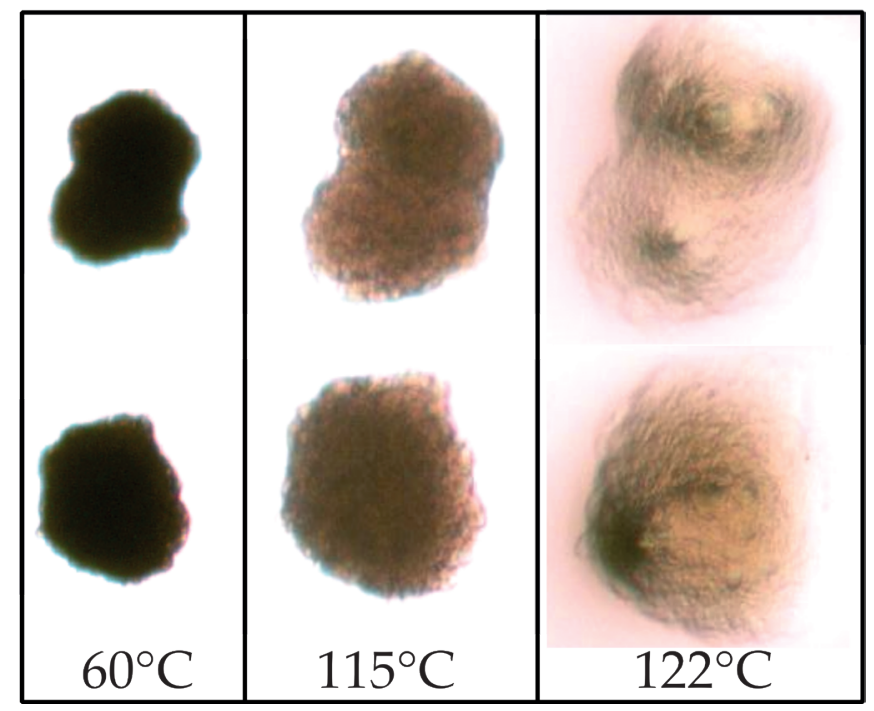

Fig. 1. Images of the characteristic stages of PVC grains swelling in PureFlex A 
a)

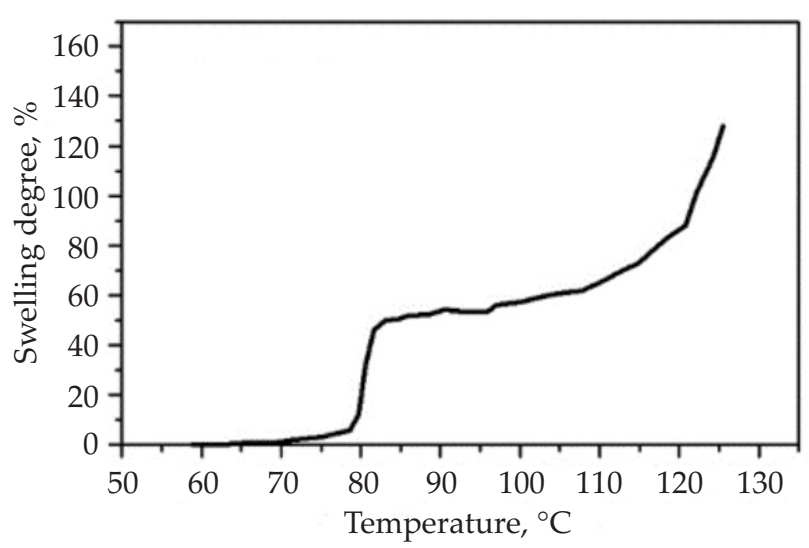

Fig. 2. Swelling curves of: a) PureFlex A, b) PureFlex B

a dry blend powder mixture did not form (maximum rotation is not present).

On plastograms recorded at $100^{\circ} \mathrm{C}$ and $120^{\circ} \mathrm{C}$ (Figs. $3 \mathrm{~b}$ and 3c), it can be seen that rotation increases and reaches a maximum value, and then slightly decreases. Having unloaded the chamber, powders composed of separate, non-sticky PVC grains were obtained. A dry blend is created under experimental conditions for approximately 10 minutes at $100^{\circ} \mathrm{C}$ and approximately 6 minutes at $120^{\circ} \mathrm{C}$. The plastograms of the PVC/PureFlex B mixture have a similar course. On this basis, it can be assumed b)

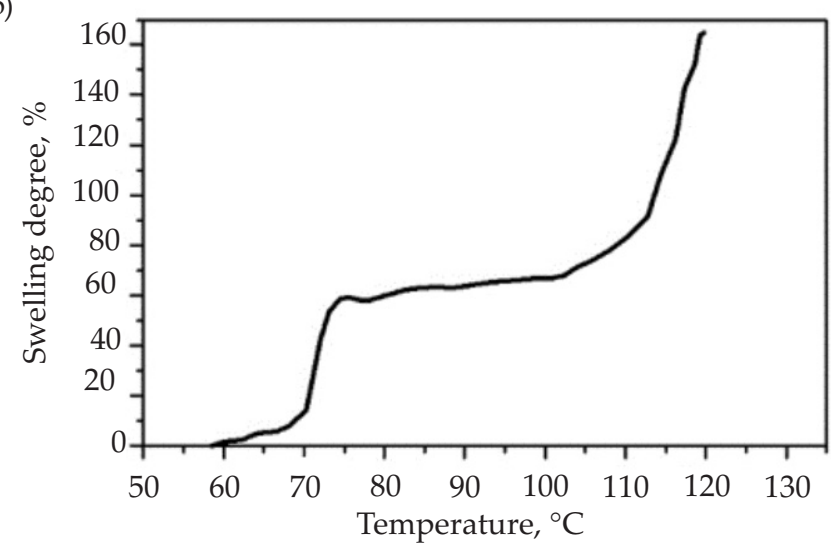

that the production process in high-speed industrial mixers, in which the temperature reaches $120^{\circ} \mathrm{C}$, should not cause any technological problems.

Figure 4, for example, shows plastograms of gelation of PVC mixtures containing 20, 30 and $40 \mathrm{phr}$ of PureFlex A. The course of plastograms of mixtures containing PureFlex B is similar. The course of plastograms is characteristic for the gelation process of plasticized PVC mixtures [40]. There is a maximum on the rotation curves. The temperature increases as a function of kneading time. Having unloaded the chamber, it was found

b)

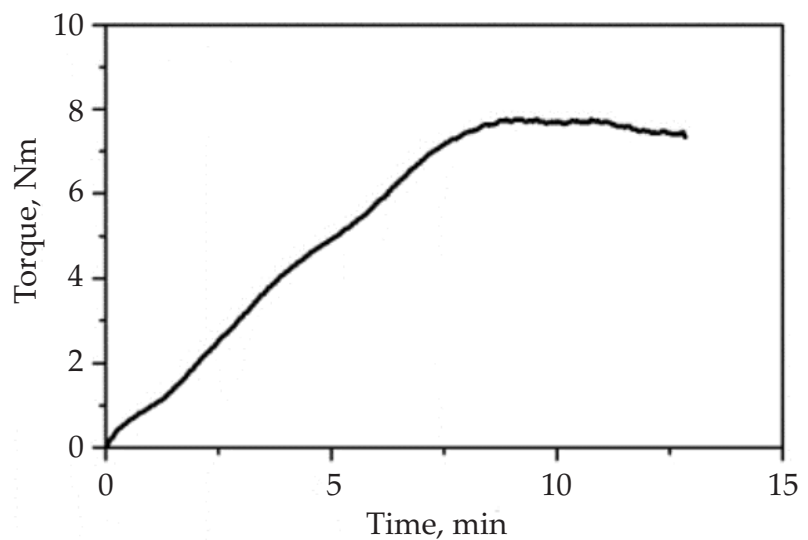

c)

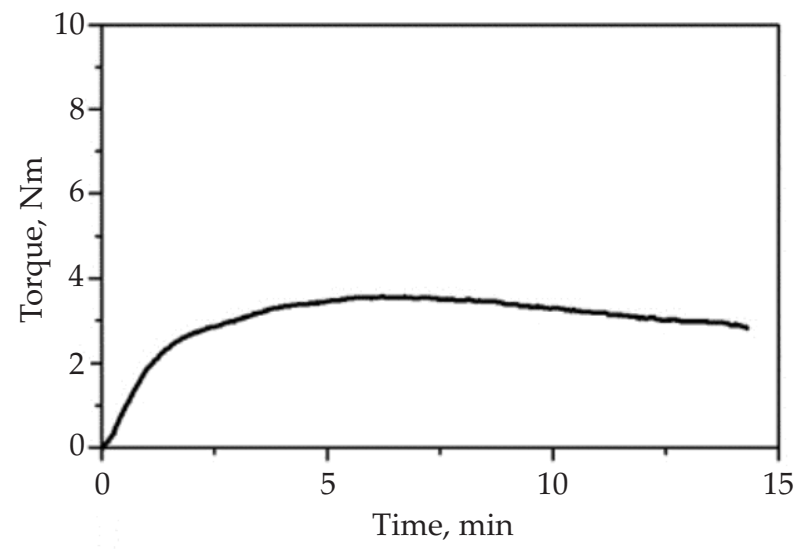

Fig. 3. Plastograms of PVC/PureFlex A mixtures in: a) $90^{\circ} \mathrm{C}$, b) $\left.100^{\circ} \mathrm{C}, \mathrm{c}\right) 120^{\circ} \mathrm{C}$ 
T a b l e 2. Values of characteristic plastogram points

\begin{tabular}{c|c|c|c|c|c|c}
\hline Plasticizer & Content, phr & $T_{x^{\prime}}{ }^{\circ} \mathrm{C}$ & $t_{x^{\prime}} \min$ & $M_{x^{\prime}} \mathrm{Nm}$ & $T_{e^{\prime}}{ }^{\circ} \mathrm{C}$ & $M_{e^{\prime}} \mathrm{Nm}$ \\
\hline PureFlex A & 20 & 165.5 & 8.6 & 24.8 & 168.6 & 23.1 \\
PureFlex B & 20 & 169.6 & 7.9 & 32.1 & 174.3 & 24.7 \\
PureFlex A & 30 & 163.7 & 5.7 & 24.4 & 168.5 & 20.1 \\
PureFlex B & 30 & 162.4 & 4.3 & 25.1 & 169.0 & 20.1 \\
PureFlex A & 40 & 152.5 & 4.5 & 18.1 & 160.9 & 15.4 \\
PureFlex B & 40 & 153.0 & 3.9 & 23.1 & 164.1 & 16.6 \\
\hline
\end{tabular}

a)

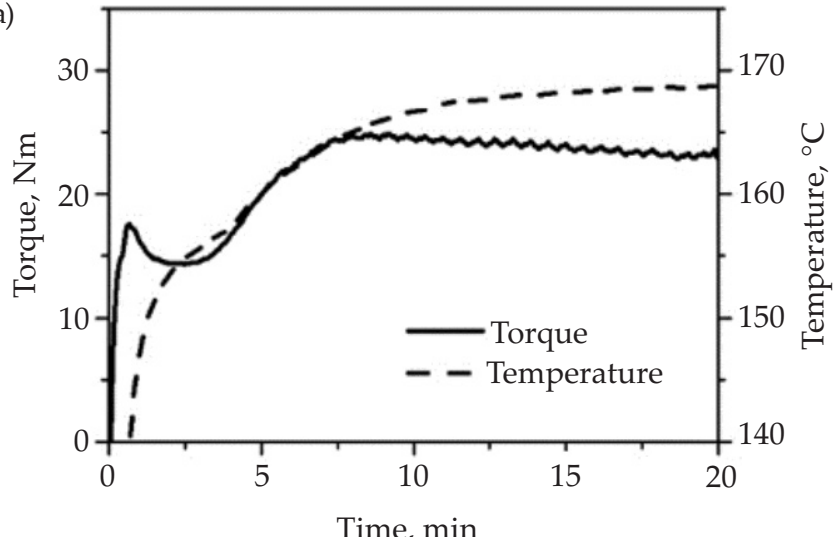

b)

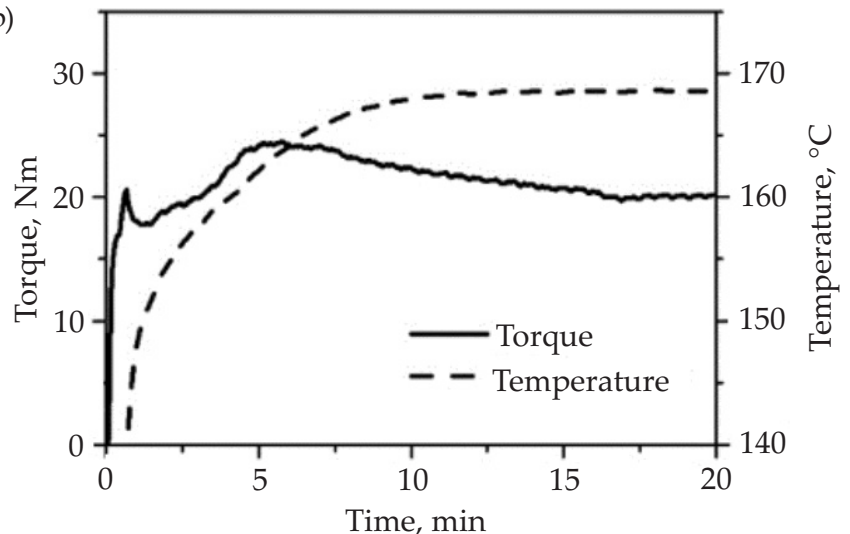

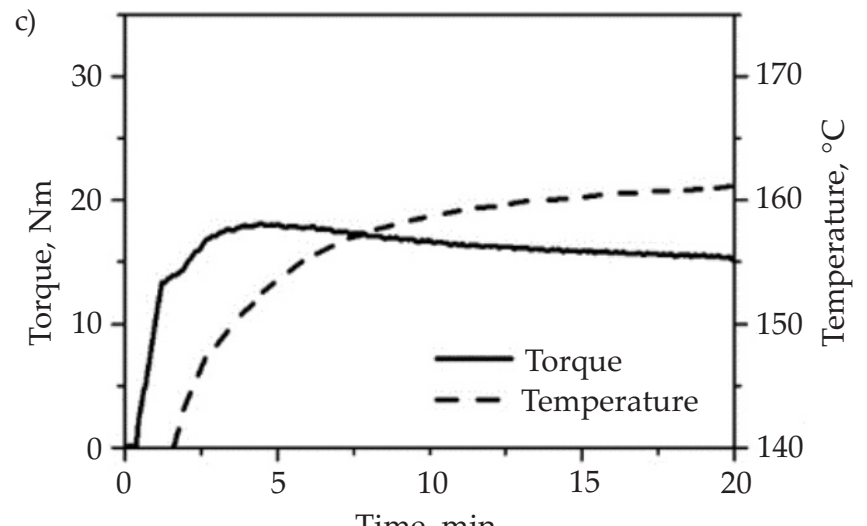

Time, $\min$

Fig. 4. Plastograms of PVC mixtures with different content of PureFlex A oligoester: a) 20 phr, b) 30 phr, c) 40 phr

that the plasticizers obtained were correctly formed, are homogeneous and have a pale straw colour similar to the color of oligoester, without signs of PVC degradation.

As the oligoester content increases, the gel time decreases and the maximum torque and temperature decrease. A significant decrease in the $M_{e}$ and $T_{e}$ values was found and summarizes in Table 2, which is associated with a significant reduction in the viscosity of the plasticized mixture as a result of the reduction of intermolecular forces. The observed changes are more associated with an increase in the content of plasticizers tested and less with their type. The obtained results showed that PureFlex A or PureFlex B oligoesters can be potential PVC plasticizers, as they can be used to form correctly formed plasticizers.

Figure 5 shows, for example, DMTA thermograms of PVC/PureFlex B plasticizers The $T_{g}$ values determined from the changes in the value $E^{\prime}$ are summarized in Table 3.
Both substances have a plasticizing effect on PVC, which is manifested by a clear reduction in the glass transition temperature.

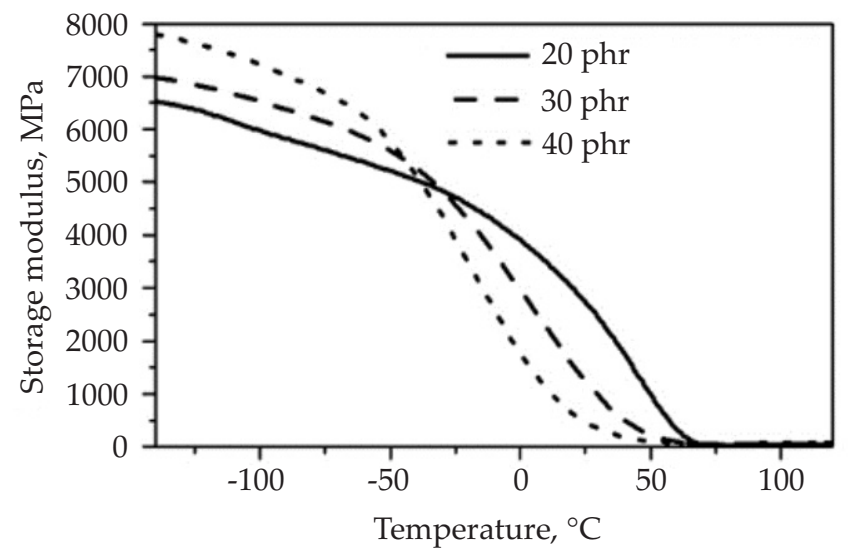

Fig. 5. DMTA thermograms of PVC/PureFlex B 
$\mathrm{T}$ a b 1 e 3. Glass transition temperature $T_{g}$ and time of thermal stability of the tested plasticized PVC

\begin{tabular}{c|c|c|c}
\hline Plasticizer & Content, phr & $T_{g}$ onset $^{\circ} \mathrm{C}$ & $\begin{array}{c}\text { Thermal } \\
\text { stability time } \\
\text { min }\end{array}$ \\
\hline PureFlex A & 20 & +22.6 & 75 \\
PureFlex B & 20 & +7.7 & 82 \\
PureFlex A & 30 & -9.1 & 78 \\
PureFlex B & 30 & -34.6 & 84 \\
PureFlex A & 40 & -33.9 & 81 \\
PureFlex B & 40 & -50.7 & 86 \\
\hline
\end{tabular}

These observations also confirm the results of the mass melt flow rate. As the proportion of plasticizer increases, the viscosity decreases, which results in an increase in the MFR value (Fig. 6).

PureFlex B turned out to be a more effective plasticizer compared to PureFlex A, although the terephthalate ring is present in the chemical structure of PureFlex A.

Table 3 summarizes the results of the measurement of thermal stability time determined with the Congo red method.

Plasticized PVC containing both tested oligoesters are characterized by good thermal stability, which allows their safe production, does not limit applications and is sufficient for material recycling. In addition, it can be stated that with the increase in the proportion of oligoesters, the thermal stability time of plasticized PVC does not deteriorate.

Table 4 presents the results of mechanical testing of soft PVC.

The analysis of the mechanical properties of soft PVC confirms the previously observed higher effectiveness of PureFlex B plasticization compared to PureFlex A. The effect of this is lower elastic modulus values and higher values of strain at strength.

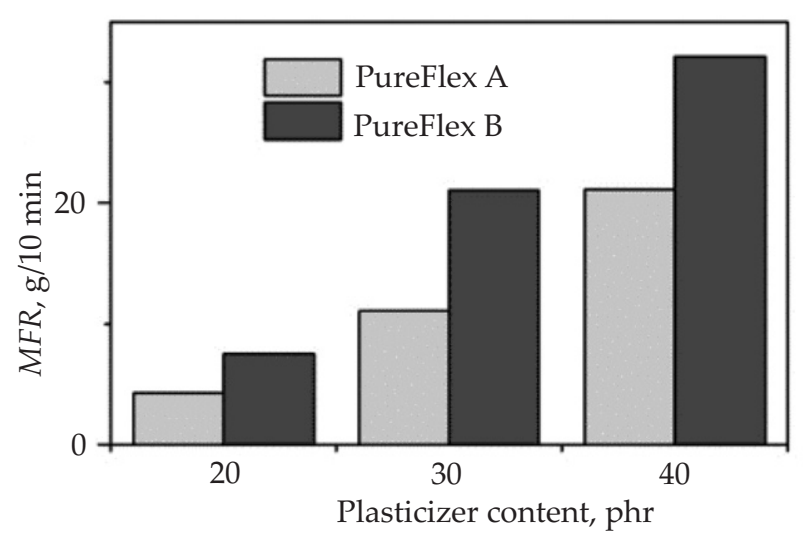

Fig. 6. Summary of the MFR measurement results of tested plasticized PVC
T a b l e 4. Strength properties of tested soft PVC

\begin{tabular}{c|c|c|c|c}
\hline Plasticizer & $\begin{array}{c}\text { Content } \\
\text { phr }\end{array}$ & $\begin{array}{c}\text { Elasticity } \\
\text { modulus } \\
\text { MPa }\end{array}$ & $\begin{array}{c}\text { Strength } \\
\text { MPa }\end{array}$ & $\begin{array}{c}\text { Strain } \\
\text { at strength } \\
\%\end{array}$ \\
\hline PureFlex A & 20 & 615 & 29 & 160 \\
PureFlex B & 20 & 304 & 24 & 170 \\
PureFlex A & 30 & 105 & 21 & 237 \\
PureFlex B & 30 & 43 & 20 & 274 \\
PureFlex A & 40 & 98 & 18 & 308 \\
PureFlex B & 40 & 20 & 16 & 322 \\
\hline
\end{tabular}

\section{CONCLUSION}

Based on the conducted tests, it can be concluded that for the initial assessment of the usefulness of the new compounds obtained for PVC plasticization, it is possible to successfully apply the tests of PVC grain swelling kinetics. It is very simple and quick to carry out the tests. Further research confirmed the effectiveness of this method.

Despite the presence of an aromatic terephthalate ring in PureFlex A (oligomeric terephthalic acid ester with polyethylene glycols), it turned out to be a less effective plasticizer compared to Pureflex B (oligomeric ester of adipic and succinic acids with diethylene glycol and 2-ethylhexyl alcohol). This is probably due to the higher molecular weight and higher content of ester groups.

Based on the analysis of the results obtained, it can be concluded that both assessed oligoesters can be successfully used for the production of plasticized PVC with utility indicators similar to those of plasticized PVC produced so far.

This research was supported by the European Regional Development Fund (POIR.01.01.01-00-0172/15-02).

\section{REFERENCES}

[1] Doolittle A.K.: "The Technology of Solvents and Plasticizers", Wiley, New York 1959.

[2] Thinius K.: "Chemie, Physik und Technologie der Weichmacher", Verlag Technik, Lipsk 1953.

[3] Houwink R., Stawierman A.: "Chimia i Technołogia Polimierow", t. 2, Moskwa 1965, pp. 254-264.

[4] Sztarman B.P.: "Płastifikacja poliwinyłchlorida", Wyd. Chimija, Moskwa 1975.

[5] Penn W.S.: "PVC Technology", Appl. Sci. Pub. London 1971.

[6] Obłój-Muzaj M., Swierz-Motysia B., Szabłowska B.: „Polichlorek winylu”, Wydawnictwa NaukowoTechniczne, Warszawa 1997.

[7] Saechtling H: „Tworzywa sztuczne- poradnik”, Wydawnictwa Naukowo-Techniczne, Warszawa 2000. 
[8] Kalińska D., Płochocka K: „Zmiękczanie tworzyw sztucznych", Wydawnictwa Naukowo-Techniczne, Warszawa 1965.

[9] Wiliński D., Łukowski P., Rokicki G.: Polimery 2016, 61, 474 . http://dx.doi.org/10.14314/polimery.2016.474

[10] Sidhharth S., Saiyam D., Manav D. et al.: Journal of Indian Chemical Engineer 2018, 61 (2), 1. https://doi.org/10.1080/00194506.2018.1529635

[11] Duc-Ha Phan-Vu, Chung-Sung Tan: Journal of RSC Advances 2017, 30. https://doi.org/10.1039/C7RA02227A

[12] Chen L., Xue W., Zeng Z.: Chemical Science International Journal 2017, 20 (1), 1. https://doi.org/10.9734/CSJI/2017/35258

[13] „Chemia polimerów” (Eds. Florjańczyk A., Pęczek S.), Oficyna Wydawnicza Politechniki Warszawskiej, Warszawa 1995.

[14] Summers J.W.: Journal of Vinyl and Additive Technology 2008, 14 (3), 105. https://doi.org/10.1002/vnl.20151

[15] Piszczek K.: Polimery 2005, 50, 765. http://dx.doi.org/10.14314/polimery.2005.765

[16] Piszczek K.: „Żelowanie suspensyjnego nieplastyfikowanego poli(chlorku winylu)", UTP Bydgoszcz 2009.

[17] Summers J.W.: Journal of Vinyl and Additive Technology 1997, 3 (2), 130. https://doi.org/10.1002/vnl.10179

[18] Szlezyngier W.: "Tworzywa sztuczne”, Wyd. Politechniki Rzeszowskiej, Rzeszów 1996.

[19] Rozporządzenie Ministra Zdrowia z dnia 08.06.2004 r. w sprawie wykazu substancji, których stosowanie jest dozwolone w procesie wytwarzania lub przetwarzania materiałów i wyrobów z tworzyw sztucznych, a także sposobów sprawdzania zgodności tych materiałów i wyrobów z ustalonymi limitami. Dz. U. 2004 r. Nr 157, poz. 1643.

[20] Obłój-Muzaj M.: Polimery 1999, 44, 356. http://dx.doi.org/10.14314/polimery.1999.356

[21] Obłój-Muzaj M.: Rynek Tworzyw 2002, 2, 23.

[22] Zarean M., Keikha M., Poursafa P. et al.: Environmental Science and Pollution Research 2016, 23, 24642. https://doi.org/10.1007/s11356-016-7648-3

[23] Shu H., Jönsson B.A.G., Gennings Ch. et al.: INDOORAIR 2019, 29 (1), 43. https://doi.org/10.1111/ina.12508

[24] „Ograniczenie stosowania niektórych niebezpiecznych substancji w wyposażeniu elektrycznym i elektronicznym", Dyrektywa UE 2011/65/UE.
[25] “Opinion on medical devices containing DEHP plasticised PVC: Neonates and other groups possibly at risk from DEHP toxicity", European Commission, Health and Consumer Protection Directorate General: December 2015.

[26] US Pat. 10273345 B2 (2019).

[27] US Pat. 10131764 B2 (2018).

[28] WO. Pat. 2016/069673 A1 (2016).

[29] Huang Y., Yu E., Li Y., Wei Z.: Journal of Applied Polymer Science 2018, 135 (32), 46542. https://doi.org/10.1002/app.46542

[30] Sirohi S., Dobhal S., Doshi M. et al.: Indian Chemical Engineer 2019, 61 (2), 206. https://doi.org/10.1080/00194506.2018.1529635

[31] Feng G., Hu L., Ma Y. et al.: Journal of Cleaner Production 2018, 189, 334. https://doi.org/10.1016/j.jclepro.2018.04.085

[32] Pyeon H.B., Park J.E., Suh D.H.: Polymer Testing 2017, 63, 375.

https://doi.org/10.1016/j.polymertesting.2017.08.029

[33] Brostow W., Lu X., Osmanson A.T.: Polymer Testing 2018, 6, 63. https://doi.org/10.1016/j.polymertesting.2018.03.007

[34] Szulc J., Lewandowski K., Skórczewska K., Sadkiewicz J.: Polimery 2018, 63, 825. http://dx.doi.org/10.14314/polimery.2018.11.12

[35] Oxoviflex, Oxovilen - oferta handlowa firmy Grupa Azoty: https://grupaazoty.com (14.02.2012).

[36] Luther H., Glander F.O., Schleese E.: Kunststoffe 1962, 52 (1), 7.

[37] Piszczek K., Skraga J., Zajchowski S., Budziak R.: „Ocena niejednorodności ziaren poli(chlorku winylu) metodą mikroskopową", Prace Wydziału Nauk Technicznych Bydgoskiego Towarzystwa Naukowego, Seria A, no 1, p. 49-60.

[38] Piszczek K., Zajchowski S., Skraga J.: Polimery 1980, 25, 176. http://dx.doi.org/1014314/polimery.1980.176

[39] Zajchowski S., Piszczek K., Tomaszewska J.: Polimery 2001, 46, 232. http://dx.doi.org/10.14314/polimery.2001.232

[40] Skraga J., Wąsicki A., Piszczek K. et al.: Polimery 1999, $44,138$. http://dx.doi.org/10.14314/polimery.1999.138

[41] Ward J.M.: „Mechaniczne własności polimerów jako tworzyw konstrukcyjnych", PWN, Warszawa 1975.

[42] Matykiewicz D., Lewandowski K., Dudziec B.: Composite Interfaces 2017, 24 (5), 489. https://doi.org/10.1080/09276440.2016.1235905

Received 21 II 2020. 